\title{
Habitat use, residency, and seasonal distribution of female leopard sharks Triakis semifasciata in Elkhorn Slough, California
}

\author{
Aaron B. Carlisle ${ }^{1,2, *}$, Richard M. Starr ${ }^{3}$ \\ ${ }^{1}$ Pacific Shark Research Center, Moss Landing Marine Laboratories, 8272 Moss Landing Road, Moss Landing, California \\ 95039, USA \\ ${ }^{2}$ Hopkins Marine Station of Stanford University, 120 Oceanview Blvd, Pacific Grove, California 93950, USA \\ ${ }^{3}$ University of California Sea Grant Extension Program, Moss Landing Marine Laboratories, 8272 Moss Landing Road, \\ Moss Landing, California 95039, USA
}

\begin{abstract}
Bays and estuaries play important roles in the life history of leopard sharks Triakis semifasciata, yet these coastal environments are among those most impacted by human activity. To better understand habitat use, spatial associations, and ecological roles of leopard sharks in estuarine environments, movements of leopard sharks were studied in Elkhorn Slough, California, USA. A total of 21 female leopard sharks (78 to $140 \mathrm{~cm}$ total length) were tagged with acoustic transmitters and tracked from August 2003 to February 2005. Eight sharks were manually tracked for 20 to $71.5 \mathrm{~h}$, and 13 sharks were monitored for 4 to $280 \mathrm{~d}$ using an array of acoustic receivers. Female leopard sharks exhibited a high degree of fidelity to Elkhorn Slough. The distribution of tagged sharks changed seasonally and was likely associated with changes in temperature, salinity, and dissolved oxygen. Sharks used the area that comprises Elkhorn Slough National Estuarine Research Reserve (ESNERR) extensively throughout the year, but especially during spring and summer. When sharks occupied ESNERR, their habitat use was tidally influenced, with sharks using low intertidal mudflats extensively when available. Sharks using the main channel tended to remain in subtidal habitats at all tidal levels. These results suggest that efforts to protect important leopard shark habitats in bays and estuaries should focus on preserving and restoring intertidal mudflats.
\end{abstract}

KEY WORDS: Acoustic monitoring • Active tracking • Triakidae • Residency • Site fidelity • Habitat use $\cdot$ Tide $\cdot$ Estuary

\section{INTRODUCTION}

Elasmobranchs (sharks, skates, and rays) commonly inhabit shallow coastal areas such as bays and estuaries (Snelson \& Williams 1981, Castro 1993, Simpfendorfer \& Milward 1993). As upper trophic level predators in these ecosystems, they likely play an important role in maintaining the composition and stability of food webs as has been demonstrated in other ecosystems (Musick et al. 2000, Stevens et al. 2000, Bascompte et al. 2005). Conversely, bays and estuaries often play an important role in determining the population structure of sharks and rays as shallow embayments are known to function as nursery areas for many elasmobranch species (Springer 1967, Castro 1993). Despite their ecological importance, estuarine habitats around the world have been degraded by human activity (Edgar et al. 2000, Whitfield \& Elliot 2002). For example, in California, USA, Larson (2001) reported that $>91 \%$ of estuarine wetlands were altered or lost in the last century. Rapid or extensive change or loss of estuarine habitat is thus an important conservation issue for species that utilize these environments, especially relatively long-lived, late maturing, and low fecundity species such as elasmobranchs. 
The leopard shark Triakis semifasciata is one of the most common nearshore sharks in California and is known to use bays and estuaries extensively (Ebert 2003). Leopard sharks of all sizes are commonly found in Elkhorn Slough (Talent 1985, Carlisle et al. 2007) and are seasonally abundant during spring, summer, and autumn (Yoklavich et al. 1991). This seasonal abundance is tied to foraging and reproduction, as leopard sharks feed on a variety of benthic invertebrates and fishes that are abundant in the slough (Talent 1976, Barry et al. 1996, Kao 2000) and use the slough as a nursery area during spring and summer (Ackerman 1971, Talent 1985, Carlisle et al. 2007).

Habitats in the Elkhorn Slough have changed greatly over the last century, mainly as a result of anthropogenic activities such as diking of marshlands for agricultural purposes, channel and jetty construction for harbor development, and destruction of levees for habitat restoration (Van Dyke \& Wasson 2005). These habitat alterations have changed the composition, abundance, and trophic patterns of the ichthyofauna of Elkhorn Slough (Lindquist 1998, Wasson et al. 2002, Yoklavich et al. 2002). Because habitat alteration has affected the prey species of leopard sharks, the sharks' diet has become less diverse than it was in the 1970s, and an ontogenetic diet shift that was previously observed has since disappeared (Ackerman 1971, Talent 1976, Kao 2000). As estuarine habitats continue to be altered directly by human disturbance or indirectly by global climate change, it is important to better understand leopard shark movements and habitat use in estuaries to be able to predict and evaluate the ecological consequences of these disturbances. In this study, we used acoustic telemetry techniques to (1) estimate residency of female leopard sharks within Elkhorn Slough, (2) determine seasonal use of different regions of Elkhorn Slough by female leopard sharks, and (3) identify patterns of habitat use by female leopard sharks within Elkhorn Slough.

\section{MATERIALS AND METHODS}

Study site. Elkhorn Slough is a shallow, highly productive seasonal estuary that is $\sim 11 \mathrm{~km}$ long, located at the head of Monterey Bay in central California (Fig. 1). The slough experiences mixed semidiurnal tides with a mean diurnal range of $1.7 \mathrm{~m}$ (Caffrey \& Broenkow 2002), and has a large central main channel and branching tidal creeks bordered by extensive mudflats and salt marshes composed primarily of pickleweed Salicornia virginica. The main channel is wider and deeper in the lower parts of the slough $(200 \mathrm{~m}$ wide and $7.5 \mathrm{~m}$ deep at the mouth), but it narrows and becomes shallower in the upper regions ( $3 \mathrm{~m}$ wide and

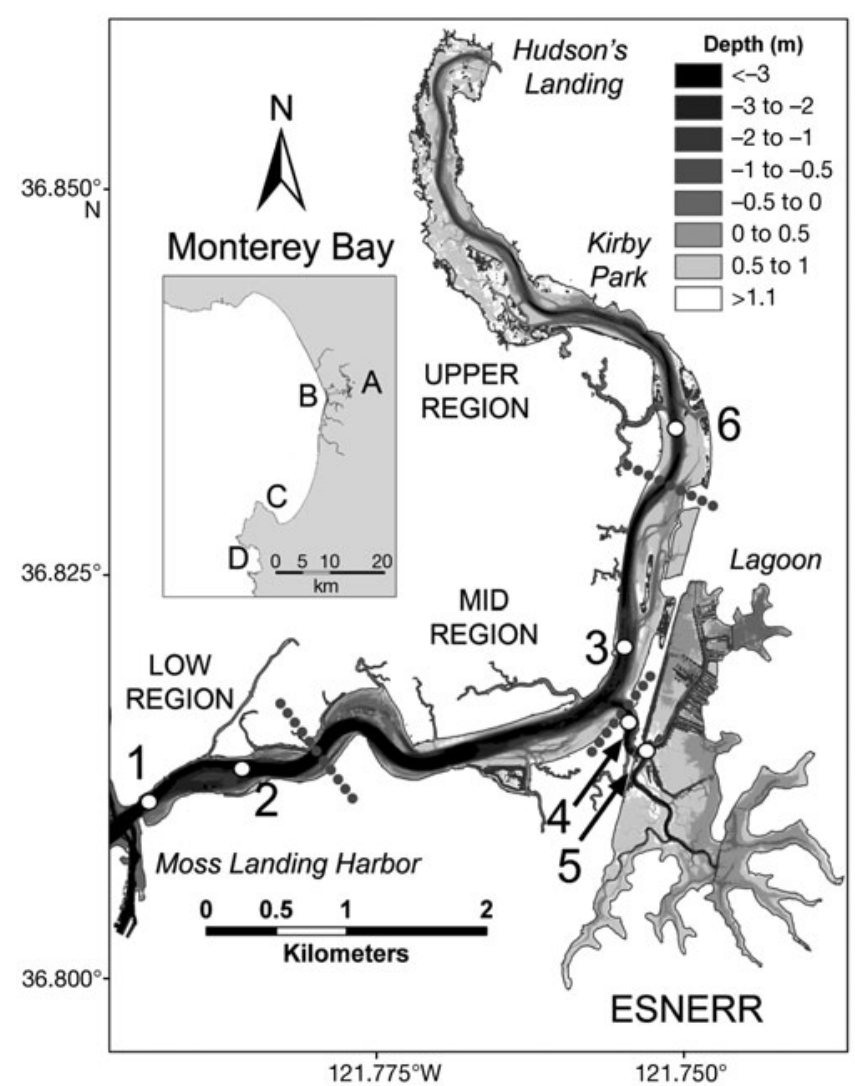

Fig. 1. Bathymetric map of Elkhorn Slough (mouth of slough is at $36.8^{\circ} \mathrm{N}, 121.8^{\circ} \mathrm{W}$ ). (O) Receiver locations labeled 1 to

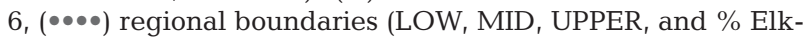
horn Slough National Estuarine Research Reserve [ESNERR]). Depth of bottom is depicted by shading: intertidal habitats in lighter shades. Inset map: A: Elkhorn Slough; B: the receiver array off Moss Landing; C: the receiver array in Monterey; D: the receiver array in Carmel Bay. Bathymetry courtesy of the NOAA Coastal Services Center and California State University Monterey Bay's Seafloor Mapping Laboratory

$1.5 \mathrm{~m}$ deep at Hudson's Landing). Substrates in Elkhorn Slough are primarily composed of organically rich muds in the upper intertidal regions, a mix of organically rich and inorganic muds and clays in lower intertidal regions, and predominantly inorganic muds and clays in the subtidal areas (Malzone 1999). Intertidal mudflats are most abundant in the Elkhorn Slough National Estuarine Research Reserve (ESNERR), which comprises the southeast portion of Elkhorn Slough, and the upper parts of the main channel.

As Elkhorn Slough is a seasonal estuary, most of the freshwater input occurs during winter rains, which depress salinity to its lowest levels. Salinity reaches a maximum in summer due to evaporation, especially in the upper and more restricted areas of the slough. Water temperatures peak in summer and are lowest in winter. Dissolved oxygen reaches lowest levels in areas farther from the mouth, especially in areas with 
restricted tidal flow. The lowest dissolved oxygen levels are encountered in late summer and autumn, corresponding with blooms of macroalgae, although low levels occasionally occur during periods of increased freshwater input, such as during winter rains. Elkhorn Slough can be divided into 2 distinct water bodies. Most of the water in the lower half to two-thirds of the slough is exchanged with ocean waters over the tidal cycle and water characteristics thus primarily reflect coastal conditions. Water in the upper slough has an extended residence time of up to $300 \mathrm{~d}$, and has generally more variable and extreme environmental conditions (Broenkow 1977, Caffrey \& Broenkow 2002, Broenkow \& Breaker 2005).

Tagging. Leopard sharks were caught using tended gillnets $(20 \times 2 \mathrm{~m}, 12.7 \mathrm{~cm}$ stretch mesh; or $15 \times 1.5 \mathrm{~m}$, $10.2 \mathrm{~cm}$ stretch mesh). In shallow waters where the float line was visible, the net was immediately checked when activity was noted, whereas the nets were checked every $10 \mathrm{~min}$ in deeper waters. There was no fishing mortality. The total length (TL, flexed) of all captured sharks was recorded, and all sharks were tagged for identification (T-bar or oval tags, Floy Tag). The catch per unit effort (CPUE, number of leopard sharks $\mathrm{h}^{-1}$ ) provided estimates of the relative abundance of sharks in ESNERR and the main channel during different seasons (spring: March through May; summer: June through August; autumn: September through November). Fishing was primarily limited to the spring, summer, and autumn as leopard sharks are reportedly less abundant in bays and estuaries during winter (Yoklavich et al. 1991, Hopkins \& Cech 2003). Moreover, the observed catch rates decreased greatly in late autumn and no sharks were caught during limited sampling in winter. In ESNERR, fishing primarily occurred at the mouth of the lagoon, while it occurred mainly in the vicinity of Kirby Park in the main channel (Fig. 1).

Acoustic transmitters (Vemco) were surgically implanted in the peritoneal cavities of female leopard sharks longer than $70 \mathrm{~cm}$ in TL. Although male and female sharks were caught, only female leopard sharks were implanted with acoustic transmitters to eliminate possible bias due to sex differences and because one of the original goals was to examine the use of Elkhorn Slough as a nursery area. Captured sharks were anesthetized by placing them in a solution $\left(0.1 \mathrm{~g} \mathrm{l}^{-1}\right)$ of tricaine methanosulfate (MS222). They were then placed on their backs on a surgical board with a constant flow of a more dilute solution of MS222 (0.05 $\left.\mathrm{g} \mathrm{l}^{-1}\right)$ passing over their gills. Acoustic transmitters were inserted through a small axial incision $(\sim 3 \mathrm{~cm})$ approximately $3 \mathrm{~cm}$ off the midline and about two-thirds of the way between the pectoral and pelvic fins. Transmitters were coated in a 2.3:1 mixture of beeswax and paraffin wax to prevent transmitter rejection (Holland et al. 1999), and then sterilized in povidone-iodine before implantation. The incision was closed using intermittent surgical sutures. Sharks were released in the slough when completely revived.

In 8 sharks, we implanted Vemco model V16-5H tags that continuously transmitted signals to enable us to monitor small spatial and temporal patterns of movement. Continuous transmitters had unique operating frequencies ranging from 51 to $75 \mathrm{kHz}$ and pulse periods of either $1 \mathrm{~s}$ (estimated battery life $65 \mathrm{~d}$ ) or $1.5 \mathrm{~s}$ (estimated battery life 95 d). In 13 sharks, we implanted Vemco V16-5H-R256 coded transmitters to monitor large spatial and temporal patterns of movement using moored receivers. Coded transmitters operated at a frequency of $69 \mathrm{kHz}$. Each tag had a unique identification code and pulse train delay of 30 to $79 \mathrm{~s}$, resulting in an estimated battery life of $425 \mathrm{~d}$.

Active acoustic tracking. After being tagged and released into the slough, sharks were allowed a minimum of $24 \mathrm{~h}$ to recuperate before tracking commenced. Sharks were tracked with a directional hydrophone and acoustic receiver (Vemco model VR60) from a shallow-drafted skiff capable of entering water $<30 \mathrm{~cm}$ deep. Every $5 \mathrm{~min}$, the boat's position was recorded using a handheld GPS (Garmin eTrex Vista, WAAS enabled, $<3 \mathrm{~m}$ accuracy), and the bearing to the shark, signal strength, receiver gain setting, and time were recorded. Care was taken to avoid disturbing sharks during tracking, although it appeared that sharks were generally not easily disturbed.

Sharks were tracked in $6 \mathrm{~h}$ blocks during 4 distinct time periods: $00: 00$ to $06: 00 \mathrm{~h}, 06: 00$ to $12: 00 \mathrm{~h}, 12: 00$ to 18:00 $\mathrm{h}$, and 18:00 to 00:00 h. Three replicate tracking sessions were conducted for each $6 \mathrm{~h}$ block, for a planned total of $72 \mathrm{~h}$ of tracking per shark, although most sharks were tracked for shorter durations. The temporal allocation of the replicate tracking sessions was haphazard, with tracking sessions being conducted so as to gather the predetermined amount of data as rapidly as possible while dealing with logistical constraints.

Active tracking data were used to calculate fixed kernel density utilization distributions (KUDs) (Worton 1989) using the Animal Movement Analysis Extension for ArcView 3.2 (Hooge \& Eichenlaub 2000). The $95 \%$ probability contours, representing total activity space, and the $50 \%$ probability contours, representing core areas of activity, were calculated for each shark to describe the activity space of the shark during the time that it was tracked in Elkhorn Slough. KUDs were calculated for different tidal levels (low, intermediate, and high) and periods of day (day, night) to determine if there were tidal or diel patterns of spatial distribution for each shark. 
Habitat use was also examined using active tracking data. Because all habitats in Elkhorn Slough are soft substrates that vary in composition by depth (Malzone 1999), we defined habitats as a function of bottom depth relative to mean lower low water (MLLW). In this manner, we defined 8 different habitats that were available for leopard sharks. Subtidal habitats were defined as those substrates (and associated water column) that were below MLLW (-0.5 m). Subtidal areas were divided into 4 groups: habitats that were $<-3,-3$ to $-2,-2$ to -1 , and -1 to $-0.5 \mathrm{~m}$ deep relative to MLLW. Low and intermediate intertidal habitats were located between MLLW and mean lower high water (MLHW); 3 habitats were designated at depths of -0.5 to 0,0 to 0.5 , and 0.5 to $1.1 \mathrm{~m}$. High intertidal habitats were those that were above MLHW (>1.1 m deep). Because the intertidal zone in Elkhorn Slough is extensive and leopard sharks forage in intertidal habitats, substrates were pooled in and just below the intertidal zone into $0.5 \mathrm{~m}$ bins to get better resolution for estimating habitat use at shallower depths.

Because patterns of habitat use varied depending on whether or not a shark was tracked primarily in shallow tidal channels and mudflats (in ESNERR) or in the main channel, principal components analysis (PCA) was used to determine if it was valid to group the sharks into ESNERR and main channel groups during low, intermediate, and high tidal levels. The PCA was conducted using Multivariate Statistical Package v. 3.13 (Kovach Computing Services). Data were log $(x+1)$-transformed and Kaiser's rule was used to determine the number of interpretable axes. The sharks were then grouped based on the results of the PCA and data for each group pooled to examine general patterns of habitat use.

To test the null hypothesis that sharks were using the habitats randomly, a $G$-test was performed on the 2 groups of sharks for each tidal level (Krebs 1999). A selection index with confidence limits, also known as the forage ratio, was calculated for each of the habitats during the different tidal levels, both for individual sharks and for the 2 groups of sharks (Krebs 1999, Manly et al. 2002). Selection indices range from 0 to $\infty$, with values $>1$ indicating selection (using a habitat to a greater extent than predicted based on its availability) and values $<1$ indicating avoidance. Finally, pairwise comparisons of selection indices for the different habitats were conducted to test for differences in habitat use. A Bonferonni correction was used to compensate for multiple pairwise comparisons.

Acoustic monitoring. Six Vemco VR1 receivers, which are single channel automated receivers capable of detecting multiple coded transmitters, were moored to the bottom around the slough (Fig. 1). The
VR1s and their moorings were initially deployed in early September 2003 and recovered in early February 2005. Receivers were retrieved for maintenance every 6 mo. Maintenance was staggered so that only one receiver was out of the water at a time, and receivers were out of the water for $<6 \mathrm{~h}$. Range testing indicated that the VR1 reception range was $\sim 400 \mathrm{~m}$. Because the slough is essentially a linear system and the reception range of the receivers is greater than the width of the channel, there is little chance that sharks can pass by receivers without being recorded. Two receivers were placed in close proximity in the lower slough to observe movement between the bay and the slough, and at the mouth of ESNERR to observe movement between ESNERR and the main channel.

The slough was divided into 4 regions for analysis: the lower slough $\left(0.35 \mathrm{~km}^{2}\right)$, the mid slough $\left(1.4 \mathrm{~km}^{2}\right)$, the upper slough $\left(1.25 \mathrm{~km}^{2}\right)$, and ESNERR $\left(1.68 \mathrm{~km}^{2}\right)$. Use of the lower, mid and ESNERR regions was inferred from patterns of detection at the different receivers. A shark was determined to be in the upper region if it was detected at Receivers 3 and 6 consecutively, followed by an extended period of time with no detections, and subsequent consecutive detections at Receivers 6 and 3. The total proportion of time spent in each region was calculated for each individual shark. To examine seasonal pattern of regional use, the time each shark spent in each region was calculated monthly. These data were then combined and expressed as the mean proportion of time $( \pm 95 \% \mathrm{CI})$ sharks spent in each region during each month.

\section{RESULTS}

\section{Catch per unit effort}

In ESNERR, CPUE of leopard sharks was greatest in spring and decreased by $\sim 4 \%$ in summer and autumn (Table 1). The decrease in summer CPUE during 2004 primarily reflects a lack of leopard shark catch in August. CPUE was high during June to July (1.04 fish $\mathrm{h}^{-1} \pm 0.43 \mathrm{SE}$ ), but no sharks were caught in August despite repeated sampling efforts and no fishing occurred in ESNERR subsequently. In the main channel, CPUE of leopard sharks increased from spring to autumn in 2004. The increase in CPUE in the main channel during summer was due to increased catch rates at Kirby Park in August, and the high catch rate in autumn reflects very high catch rates at Kirby Park in September. CPUE was high when fishing started in late March 2004, suggesting that sharks were already abundant by that time. Few sharks were caught in Elkhorn Slough after October. 
Table 1. Summary of leopard shark catch per unit effort (CPUE, no. of sharks $\mathrm{h}^{-1} \pm \mathrm{SE}$ ) in ESNERR and the main channel in spring, summer, and autumn of 2003 and 2004. No fishing occurred in winter. The ESNERR region includes all of ESNERR and the channel leading to it, and the main channel includes all areas fished in the main channel, primarily Kirby Park. Hours indicates the total fishing time; dashes indicate that no fishing occurred

\begin{tabular}{|c|c|c|c|c|c|c|c|}
\hline \multirow[t]{2}{*}{ Year } & \multirow[t]{2}{*}{ Region } & \multicolumn{2}{|c|}{ Spring } & \multicolumn{2}{|c|}{ Summer } & \multicolumn{2}{|c|}{ Autumn } \\
\hline & & CPUE & Hours & CPUE & Hours & CPUE & Hours \\
\hline \multirow[t]{2}{*}{2003} & ESNERR & $0.80 \pm 0.8$ & 7.0 & $0.42 \pm 0.4$ & 8.1 & $0.41 \pm 0.1$ & 18.8 \\
\hline & $\begin{array}{c}\text { Main } \\
\text { channel }\end{array}$ & - & - & - & - & - & - \\
\hline \multirow[t]{2}{*}{2004} & ESNERR & $0.90 \pm 0.3$ & 27.7 & $0.47 \pm 0.2$ & 35.0 & - & - \\
\hline & $\begin{array}{c}\text { Main } \\
\text { channel }\end{array}$ & $0.60 \pm 0.3$ & 25.0 & $1.05 \pm 0.4$ & 25.5 & $5.4 \pm 4.3$ & 5.0 \\
\hline
\end{tabular}

\section{Tagging}

Twenty-one female sharks were tagged with acoustic transmitters between spring and autumn of 2003 and 2004 (Tables 2 \& 3). All sharks revived rapidly after surgery and swam away in apparently good condition. One shark died a day after tagging despite appearing healthy upon release. The shark was recovered, but the cause of death was not apparent although it was likely a combination of thermal and handling stress, as water and air temperatures were at the highest point in the year and the handling time was longer than normal. Another shark (108) was recaptured with ruptured sutures $12 \mathrm{~d}$ after being released. The tag had not been expelled and the shark was not acting abnormally, so the wound was cleaned and resutured, and the shark was released. Movements of this shark were similar to those of others for the rest of the study, indicating that it had survived the incident.

\section{Active tracking}

Eight female sharks were tagged with continuous transmitters and tracked for a total of $432 \mathrm{~h}$ (Table 2, Fig. 2). Based on age and growth estimates from Kusher et al. (1992), one shark was a juvenile $(<105 \mathrm{~cm} \mathrm{TL})$ and the rest were adults (>105 cm TL). Sharks ranged in length from 91 to $132 \mathrm{~cm}$ TL (mean $119.4 \mathrm{~cm} \pm$ 4.8 SE). The duration of tracking for each shark was 19.9 to $71.4 \mathrm{~h}$ (mean $54.0 \mathrm{~h} \pm$ 7.5 SE). Total distance traveled ranged from 9.9 to $68.0 \mathrm{~km}$ (mean $39.1 \mathrm{~km} \pm$ 7.6 SE), and total activity space (95\% KUD) ranged from 0.2 to $1.8 \mathrm{~km}^{2}$ (mean $0.9 \mathrm{~km}^{2} \pm 0.2 \mathrm{SE}$ ). All tagged sharks vacated the slough by early December. Sharks were tracked primarily in either ESNERR or the main channel, and did not tend to move between these regions during the $6 \mathrm{~h}$ tracking sessions.

The PCA indicated that habitat use by sharks strongly clustered into ESNERR and main channel groups during low, intermediate, and high tidal levels. For intermediate and high tidal levels, the first principal component (PC1) exhibited a bipolar trend in which the ESNERR group was loaded negatively, indicating use of shallower habitats, and the main channel group was loaded positively, indicating use of deeper habitats. At low tidal levels, the pattern was weaker as a result of sharks being restricted to similar subtidal habitats, although the grouping was still apparent. PC1 and the second principal component (PC2) respectively accounted for 70.3 and $23.9 \%$ of

Table 2. Summary data for 8 female leopard sharks tagged with continuous transmitters and actively tracked in Elkhorn Slough, California in 2003 and 2004. The table reports shark tag number, stage based on Kusher et al. (1992) (A: adult, >105 cm TL; J: juvenile, <105 cm TL), date and location of tagging (E: ESNERR; MC: main channel), total length (TL), hours tracked, number of blocks tracked (number of tracking sessions during the different pre-defined blocks of time; goal was $\mathrm{n}=3$; see 'Materials and methods: Active acoustic tracking' for more details), dates of tracking (if tracking primarily occurred during a particular period of time, this is indicated in parentheses), activity space (95\% kernel utilization distribution, KUD), and total distance traveled (km)

\begin{tabular}{|c|c|c|c|c|c|c|c|c|c|}
\hline Shark & Stage & $\begin{array}{c}\text { Date } \\
\text { tagged } \\
(\mathrm{mo} / \mathrm{d} / \mathrm{yr})\end{array}$ & $\begin{array}{l}\text { Tagging } \\
\text { tocation }\end{array}$ & $\begin{array}{l}\mathrm{TL} \\
(\mathrm{cm})\end{array}$ & $\begin{array}{l}\text { Hours } \\
\text { tracked } \\
\text { (h:min) }\end{array}$ & $\begin{array}{c}\text { Blocks } \\
(0: 00 / 6: 00 / \\
12: 00 / 18: 00)\end{array}$ & $\begin{array}{l}\text { Dates tracked } \\
(\mathrm{mo} / \mathrm{d} / \mathrm{yr})\end{array}$ & $\begin{array}{c}95 \% \text { KUD } \\
\left(\mathrm{km}^{2}\right)\end{array}$ & $\begin{array}{c}\text { Total } \\
\text { distance } \\
\text { traveled }(\mathrm{km})\end{array}$ \\
\hline \multicolumn{10}{|l|}{2003} \\
\hline 54 & A & 05/12/03 & $\mathrm{E}$ & 131 & $54: 04$ & $2 / 3 / 4 / 3$ & 05/13/03-08/06/03 (July) & 0.61 & 37.71 \\
\hline 57 & $\mathrm{~A}$ & $11 / 10 / 03$ & E & 129 & $19: 55$ & $0 / 0 / 2 / 2$ & $11 / 12 / 03-11 / 18 / 03$ & 0.94 & 9.90 \\
\hline \multicolumn{10}{|l|}{2004} \\
\hline 60 & $\mathrm{~A}$ & 05/04/04 & E & 127 & $70: 05$ & $3 / 3 / 3 / 3$ & 05/06/04-06/24/04 (Мay) & 0.21 & 66.35 \\
\hline 63 & $\mathrm{~A}$ & 06/02/04 & $\mathrm{E}$ & 117 & $62: 40$ & $2 / 3 / 3 / 3$ & 06/05/04-08/04/04 (June) & 0.89 & 68.03 \\
\hline 51 & $\mathrm{~A}$ & 07/07/04 & E & 132 & 61:05 & $3 / 3 / 3 / 3$ & 07/08/04-09/16/04 (July) & 0.73 & 33.23 \\
\hline $57 \mathrm{~A}$ & $\mathrm{~A}$ & 09/02/04 & $\mathrm{MC}$ & 115 & $22: 25$ & $0 / 2 / 2 / 0$ & 09/03/04-09/10/04 & 0.69 & 12.02 \\
\hline $54 \mathrm{~A}$ & $\mathrm{~J}$ & $09 / 24 / 04$ & $\mathrm{MC}$ & 91 & $70: 35$ & $3 / 4 / 4 / 4$ & $09 / 25 / 04-11 / 12 / 04$ & 1.75 & 39.92 \\
\hline 75 & $\mathrm{~A}$ & $10 / 22 / 04$ & $\mathrm{MC}$ & 114 & $71: 25$ & $3 / 3 / 3 / 3$ & $10 / 23 / 04-11 / 12 / 04$ & 1.50 & 45.98 \\
\hline
\end{tabular}




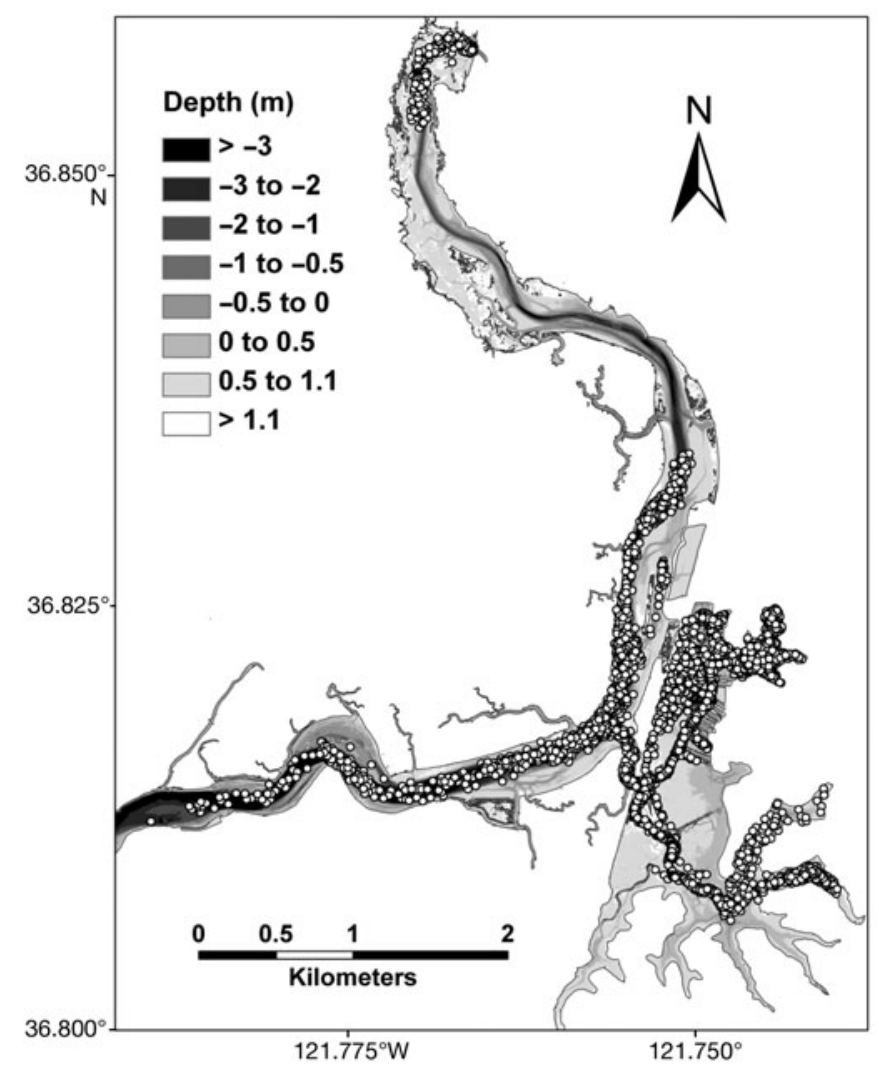

Fig. 2. Elkhorn Slough showing all leopard shark positions (O) determined using active tracking and the shark was always detected by one of these receivers. Most sharks vacated the slough by early December, although several appear to have spent the winter in the slough. Shark 105 was killed by bow hunters in the upper slough in the region above Kirby Park on July 4, 2004, and the tag was reacquired and redeployed on shark 105A.

All of the leopard sharks tagged with coded transmitters were detected at other receiver arrays in the Monterey Bay region (Fig. 3). Sharks were detected at arrays off Monterey, CA $\left(36.632^{\circ} \mathrm{N}, 121.919^{\circ} \mathrm{W}\right.$; $\sim 22 \mathrm{~km}$ distant) (J. Freiwald pers. comm.), Carmel Bay, CA $\left(36.543^{\circ} \mathrm{N}, 121.837^{\circ} \mathrm{W}_{\text {; } ~} 25 \mathrm{~km}\right.$ distant) (R. M. Starr unpubl. data), and off Moss Landing $\left(36.804^{\circ} \mathrm{N}\right.$, $121.795^{\circ} \mathrm{W}$; just off the mouth of Elkhorn Slough) (R. M. Starr \& C. Dawson unpubl. data). Sharks were primarily detected at the other receiver arrays in autumn and winter, and all of the tags were detected in late 2006 and early 2007, indicating that the V-16 tags lasted as long as $3.5 \mathrm{yr}$, which is much longer than the predicted battery life of $425 \mathrm{~d}$.

Several tagged sharks ceased to be detected in the slough after being last detected at Receiver 6 (Sharks 103, 105A, 116) or Receiver 5 (Sharks 104, 108). However, all of these sharks were detected at receiver arrays outside of Elkhorn Slough after the removal of the receivers in February 2005 at the conclusion of the study (Fig. 3). As it was highly unlikely that the sharks left the slough without being detected by any of the the variability in habitat use at high tidal levels, 66.4 and $23.0 \%$ of the variability at intermediate tidal levels, and 48.4 and $30.8 \%$ of the variability at low tidal levels. The results of the PCA indicate that it was justified to pool the sharks into ESNERR and main channel groups at low $(<0.5 \mathrm{~m})$, intermediate $(0.5$ to $1.1 \mathrm{~m})$, and high tidal levels (>1.1 m).

\section{Acoustic monitoring}

Thirteen female sharks (3 juveniles, 10 adults) were tagged with coded transmitters (Table 3). Lengths of tagged sharks ranged from 78 to $140 \mathrm{~cm}$ TL (mean $115.9 \mathrm{~cm} \pm 5.3 \mathrm{SE}$ ). Sharks were acoustically monitored in Elkhorn Slough for 4 to $280 \mathrm{~d}$ (mean $117.0 \mathrm{~d} \pm$ 101.9 SE). During the study, there were very few instances of a shark moving past a receiver without being detected. This only occurred at Receiver 4 or 5,
Table 3. Summary data for 13 female leopard sharks tagged with coded transmitters and monitored in Elkhorn Slough, CA in 2003 and 2004. The table reports shark tag number, stage based on Kusher et al. (1992) (A: adult, $105 \mathrm{~cm}$ TL; $\mathrm{J}$ : juvenile, $105 \mathrm{~cm} \mathrm{TL}$ ), date and location of tagging (E: ESNERR; MC: main channel), total length (TL), dates monitored (time from initial tagging to last detection, days indicates the number of days during this time frame that the shark was known with certainty to be in Elkhorn Slough; ${ }^{*}$ indicates that sharks were likely in the slough until the receivers were removed on 3 Feb 2005), and total number of detections at VR1 receivers

\begin{tabular}{|c|c|c|c|c|c|c|}
\hline Shark & Stage & $\begin{array}{c}\text { Date } \\
\text { tagged } \\
(\mathrm{mo} / \mathrm{d} / \mathrm{yr})\end{array}$ & $\begin{array}{l}\text { Tagging } \\
\text { location }\end{array}$ & $\begin{array}{l}\mathrm{TL} \\
(\mathrm{cm})\end{array}$ & $\begin{array}{l}\text { Dates monitored } \\
\text { (mo/d/yr) (days) }\end{array}$ & $\begin{array}{c}\text { Total } \\
\text { detections }\end{array}$ \\
\hline \multicolumn{7}{|l|}{2003} \\
\hline 100 & A & 08/29/03 & E & 127 & 08/29/03-11/14/04 (132) & 7472 \\
\hline 106 & A & 09/09/03 & $\mathrm{E}$ & 124 & 09/09/03-09/23/03 (14) & 1280 \\
\hline 107 & A & $10 / 10 / 03$ & E & 135 & 10/10/03-12/01/03 (52) & 3735 \\
\hline \multicolumn{7}{|l|}{2004} \\
\hline 105 & A & $03 / 25 / 04$ & $\mathrm{E}$ & 140 & 03/25/04-07/04/04 (101) & 11856 \\
\hline 102 & A & 03/29/04 & E & 120 & 03/29/04-11/13/04 (229) & 9222 \\
\hline 101 & A & 04/16/04 & $\mathrm{E}$ & 136 & 04/16/04-04/20/04 (4) & 862 \\
\hline 103 & $\mathrm{~J}$ & 04/27/04 & $\mathrm{E}$ & 97 & 04/27/04-07/12/04 (76*) & 5059 \\
\hline 104 & $\mathrm{~J}$ & 04/27/04 & $\mathrm{E}$ & 78 & 04/27/04-10/30/04 (186*) & 512 \\
\hline 108 & $\mathrm{~J}$ & $04 / 27 / 04$ & $\mathrm{E}$ & 85 & $04 / 27 / 04-10 / 15 / 04\left(171^{*}\right)$ & 5543 \\
\hline 109 & A & 08/13/04 & $\mathrm{MC}$ & 114 & 08/13/04-11/10/04 (89) & 11838 \\
\hline $105 \mathrm{~A}$ & A & 08/20/04 & $\mathrm{MC}$ & 122 & 08/20/24-08/26/04 (6*) & 9 \\
\hline 115 & A & 08/20/04 & $\mathrm{MC}$ & 111 & 08/20/04-11/13/04 (76) & 13146 \\
\hline 116 & A & 08/20/04 & $\mathrm{MC}$ & 118 & 08/20/04-08/22/04 (2*) & 6 \\
\hline
\end{tabular}




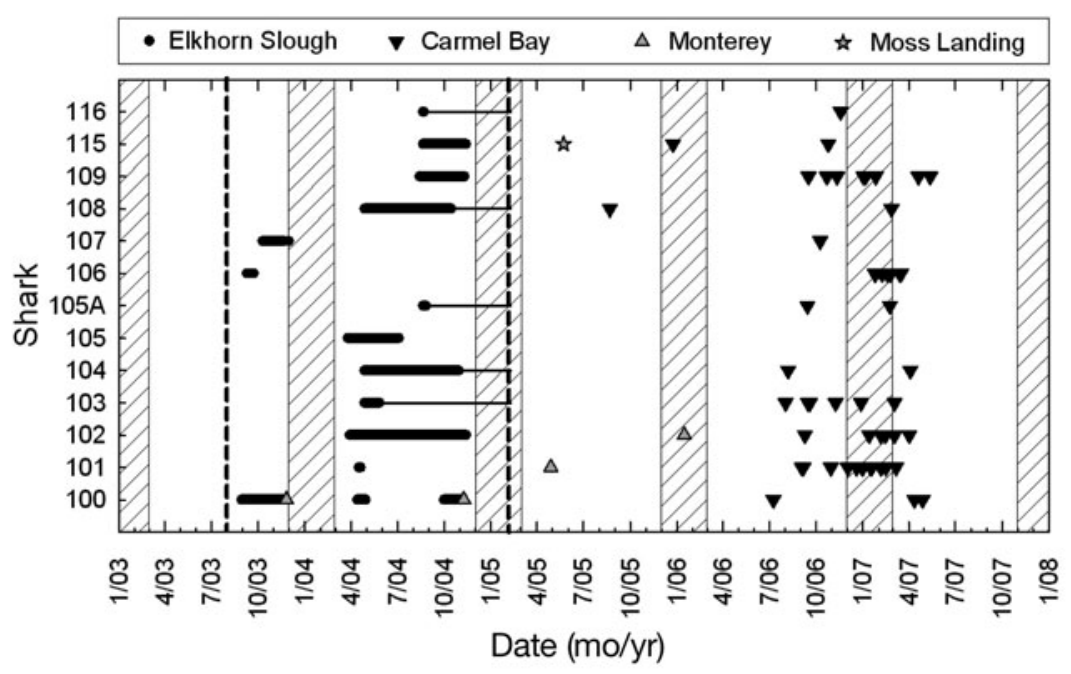

Fig. 3. Detections at acoustic receivers in Elkhorn Slough and other receiver arrays in the Monterey Bay region. Winter is depicted with hatched boxes. Vertical dashed lines show dates of deployment and retrieval of receivers in Elkhorn Slough. Elkhorn Slough data show duration of time sharks were known to be within Elkhorn, while data for other receiver arrays indicate date of detection. For Sharks 103, 104,105A, 108 and 116, the thin horizontal line indicates the time the sharks are believed to have remained in Elkhorn Slough after their last detection at Receiver 5 or 6 (see 'Results: Acoustic monitoring')

receivers, this suggests that the sharks remained in ESNERR or the upper region from the time of their last detection at Receiver 5 or 6 until some period after the receivers were removed. Although we believe that these sharks remained in either ESNERR or the upper region, the analysis of the use of the different regions of the slough by these sharks only included the period of time until their last detection in order to be conservative.

Of the 3 sharks tagged in 2003, only Shark 100 returned the following year. In addition, this shark was also the only one in the study to leave the slough and return in the same season. In 2004, it was present in Elkhorn Slough for part of April and for $\sim 1$ mo in October. After leaving the slough in November, Shark 100 moved south and was detected at Monterey Bay the following day during both 2003 and 2004. After vacating Elkhorn Slough in November 2004, Shark 115 was detected by a VR2 receiver placed just outside the mouth of Moss Landing Harbor in Monterey Bay in May 2005. The timing of the detection and the location of the receiver suggests that this shark may also have returned to Elkhorn Slough.

\section{Residency}

The average amount of time leopard sharks spent in the different regions of the slough changed seasonally (Fig. 4). During autumn 2003, tagged sharks used ESNERR extensively, but use of this area decreased slightly later in the year just before the sharks left the slough. The amount of time sharks spent in ESNERR ranged from $97 \%$ in September to $74 \%$ in November. Shark use of the mid region of Elkhorn Slough was greatest during November, when sharks spent $14 \%$ of their time in this region. In 2004, a general trend was observed in which sharks used the ESNERR region throughout most of the year, but increased use of the main channel later in the year. In spring, tagged sharks spent the majority of their time $(78 \%$ in April to nearly $100 \%$ in May) in the ESNERR region. The amount of time sharks spent in ESNERR during summer decreased slightly from $82 \%$ in June to $\sim 70 \%$ in July and August. In autumn, the percentage of time sharks spent in ESNERR ranged from $42 \%$ in September to $52 \%$ in October. Whereas shark use of ESNERR decreased in autumn, use of the upper and mid regions of

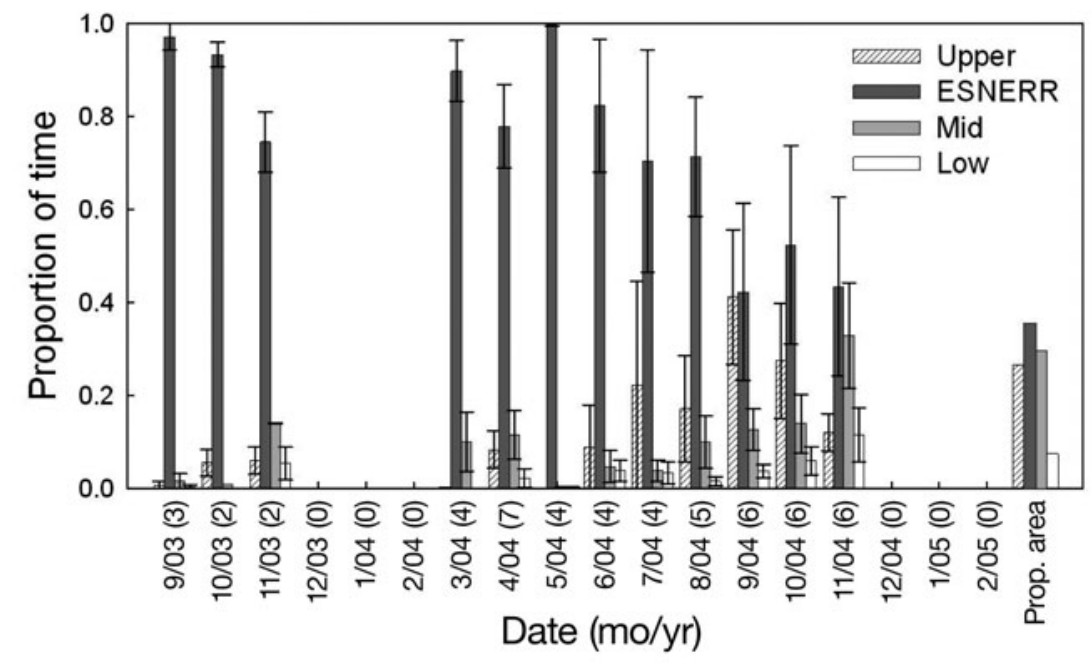

Fig. 4. Seasonal pattern of regional utilization of Elkhorn Slough based on acoustic monitoring data. Values are the mean proportion of time $( \pm \mathrm{SE})$ spent in each region by all acoustically monitored sharks in the slough during a particular month. Number of sharks in the slough during each month is shown in parentheses after the date on the $x$-axis labels. All tagged sharks were absent from the slough in winter 2003-2004. For the 5 sharks that were last detected at Receiver 5 or 6 (103, $104,105 \mathrm{~A}, 108$, and 116), only the period of time until their last detection is included (see 'Results: Acoustic monitoring'). The proportion of the total area of Elkhorn Slough that is comprised by the different regions is shown on the far right 
the main channel were most intensive at this time. Use of the upper region was greatest in September, when sharks spent $41 \%$ of their time in this region, and use of the mid zone was greatest in November, when $32 \%$ of shark time was spent in this region. The degree of shark usage of the upper region and ESNERR in late 2004 and early 2005 is probably a conservative estimate because we believe that several sharks remained in these regions (Sharks 103, 105A, and 116 in the upper region; 104 and 108 in ESNERR) through the winter until the conclusion of the study in February 2005.

\section{Distribution and movements}

\section{Activity space}

Five sharks $(51,54,57,60$, and 63$)$ that were actively tracked remained primarily in ESNERR during spring and summer. The activity spaces (95\% KUD) of the sharks tracked primarily within ESNERR ranged from 0.2 to $0.9 \mathrm{~km}^{2}$ (mean $0.7 \mathrm{~km}^{2} \pm 0.1 \mathrm{SE}$ ) (Fig. 5), and were not influenced by time of day. The sharks were influenced by tidal level. Sharks were restricted to deeper channels during low tidal levels. During flood tides, sharks moved out of deeper channels up onto intertidal mudflats, where they remained until the tide started to ebb. As water levels declined, they left the mudflats and moved back to deeper channels where they remained until the next flood tide. These movements were regular and predictable, and are exemplified by Shark 60 (Fig. 6).

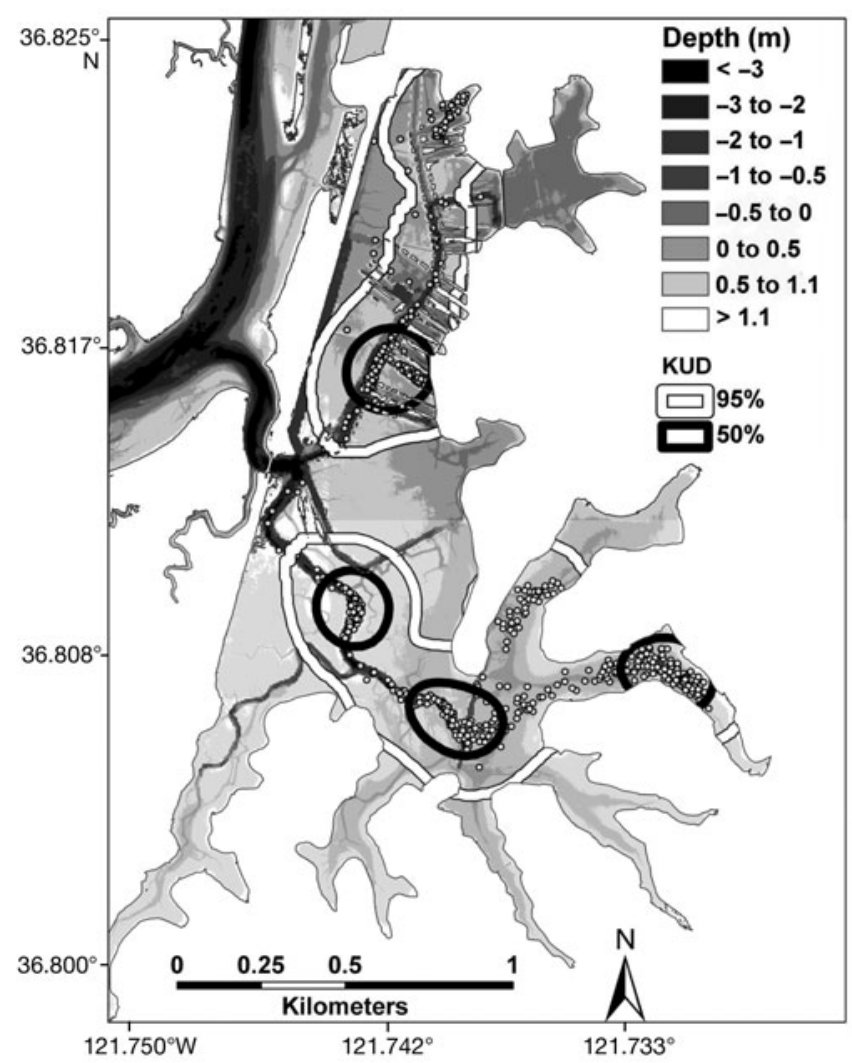

Fig. 5. Representative distribution of positions and kernel utilization distribution (KUD) for Shark 51 tracked in ESNERR. (O) Individual locations. Positions in deeper areas were primarily during lower tidal levels; those in shallower areas were primarily at higher tidal levels. The shark was tracked for $61 \mathrm{~h}$ between July 8 and September 16, 2004, but primarily during July
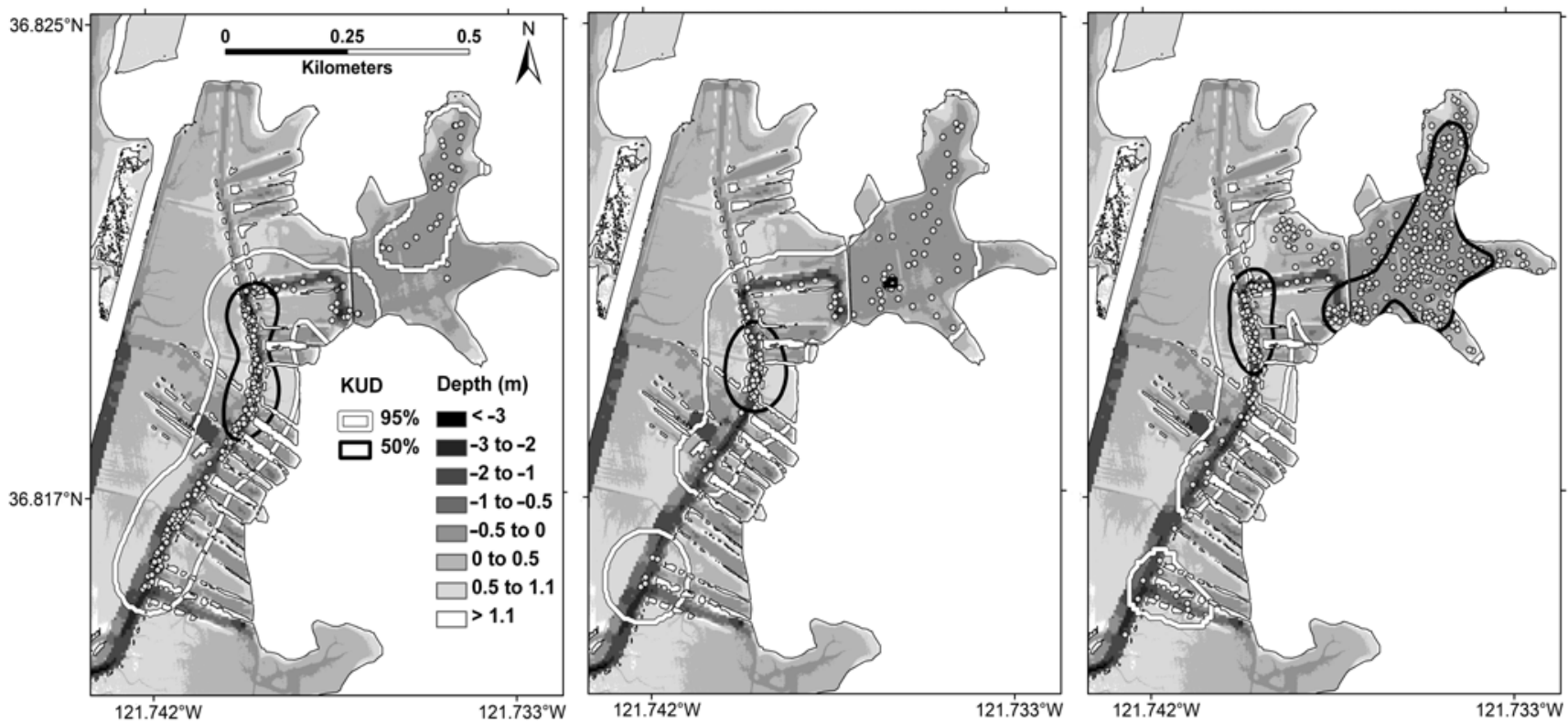

Fig. 6. Kernel utilization distributions (KUD) of Shark 60 at (a) low, (b) intermediate, and (c) high tidal levels, showing tidally influenced movements from deeper channels at low tide to shallower intertidal areas at higher tidal levels. The shark was tracked for 70 h between May 6 and June 24, 2004, but primarily during May 
Three sharks (57A, 54A, 75) that were primarily tracked in the main channel during autumn exhibited patterns of movement that differed from those shown by sharks in ESNERR. The former sharks rarely occurred on intertidal mudflats and their movements were not as influenced by the tides. Their activity spaces were greater than those of ESNERR sharks, ranging from 0.7 to $1.8 \mathrm{~km}^{2}$ (mean of $1.3 \mathrm{~km}^{2} \pm 0.3 \mathrm{SE}$ ) (Fig. 7), and they were not influenced by time of day. Although these sharks were not as obviously influenced by tides as were the sharks in ESNERR, they generally occurred further up the main channel at higher tidal levels and lower in the main channel at lower tidal levels.

\section{Habitat use}

Overall habitat use by the 2 groups of sharks was significantly different from predictions based on area of habitat $(p<0.001)$. This implies that sharks did not

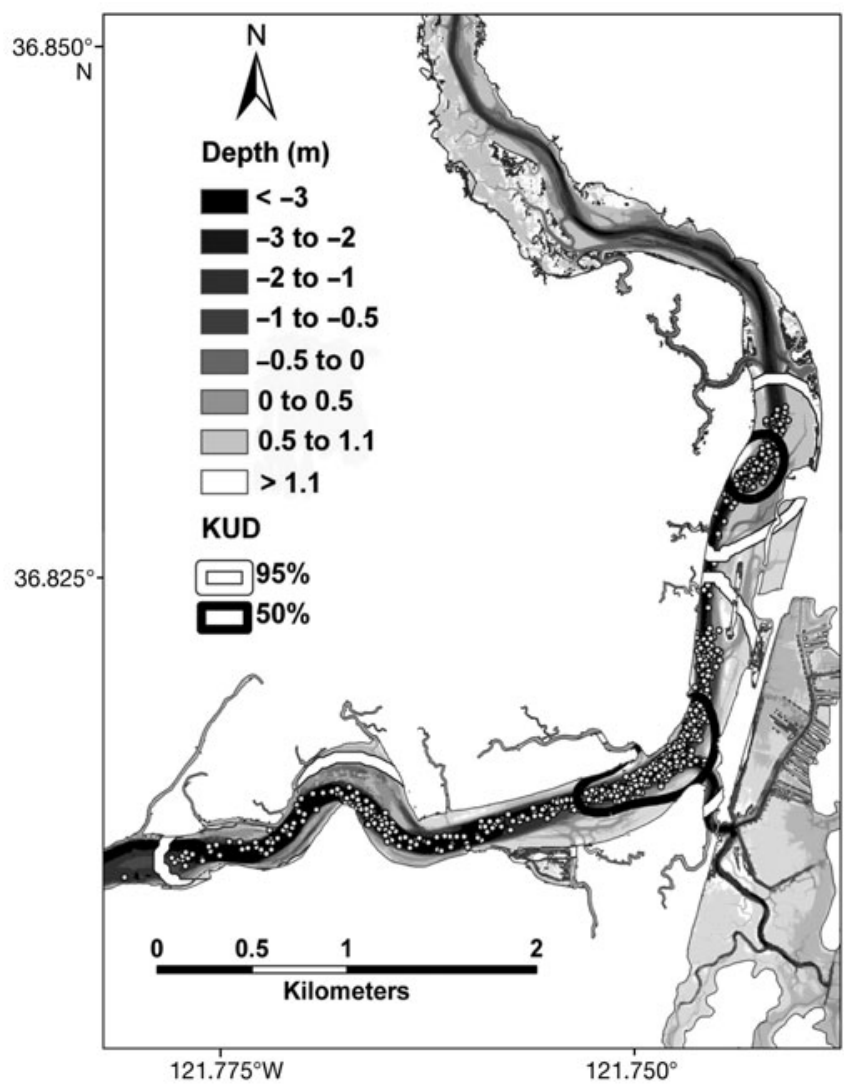

Fig. 7. Representative distribution of positions and kernel utilization distribution (KUD) for Shark 75 tracked in the main channel. (O) Individual locations. Positions lower in the channel were primarily at lower tidal levels; those in the upper channel were primarily during higher tidal levels. The shark was tracked for $71 \mathrm{~h}$ between October 23 and November 11, 2004 randomly use habitats. Patterns of habitat use, however, differed depending on whether a shark was in the main channel or at ESNERR. Sharks tracked in the main channel primarily used subtidal habitats, and habitat use was not strongly influenced by tides (Fig. 8). At low tidal levels, sharks in the main channel used deep subtidal habitats. They used the $<-3$ and -3 to $-2 \mathrm{~m}$ habitats most intensively, and used the $<-3 \mathrm{~m}$ habitats significantly more than all the other habitats ( $p$-values ranged from $<0.025$ to $<0.001$ ). At intermediate tidal levels, sharks used habitats similar to those used at lower tidal levels, although they increased their use of shallower habitats. Sharks used the -3 to -2 and $<-3 \mathrm{~m}$ habitats intensively, but the -3 to $-2 \mathrm{~m}$ habitats were used significantly more than all other habitats $(\mathrm{p}<0.001)$. At high tidal levels, sharks used shallower habitats more than during lower tidal levels, but still did not use intertidal habitats to any great degree. They used the -3 to $-2,-2$ to -1 , and -1 to $-0.5 \mathrm{~m}$ habitats most intensively. These habitats were used significantly more than all other habitats $(p<0.001)$.

Habitat use by sharks in ESNERR was tidally influenced (Fig. 8), and sharks utilized intertidal mudflats extensively. At low tidal levels, sharks in ESNERR primarily utilized subtidal habitats. Sharks used the -2 to -1 m habitats significantly more than all other habitat types ( $p<0.001)$. At intermediate tidal levels, shark use of shallower habitats in ESNERR increased. Sharks used the -2 to -1 and -0.5 to $0 \mathrm{~m}$ habitats most intensively, but the -0.5 to $0 \mathrm{~m}$ habitats were used significantly more than the -2 to $-1 \mathrm{~m}$ habitats ( $\mathrm{p}<0.025)$. Sharks used the $<-3$ and 0.5 to $1 \mathrm{~m}$ habitats significantly less than all other habitats $(\mathrm{p}<0.001)$. At high tidal levels, when all habitats were available, sharks almost exclusively used low intertidal habitats. The -0.5 to $0 \mathrm{~m}$ habitats were used significantly more than the 0 to $0.5 \mathrm{~m}$ habitats ( $\mathrm{p}<0.001$ ), and both of these habitats were used significantly more than all other habitat types $(\mathrm{p}<0.001)$. All other habitats were avoided, although the highest habitats $(>1.1 \mathrm{~m})$ were the habitat type most avoided and used significantly less than all other habitat types $(p<0.001)$.

The low intertidal mudflats that leopard sharks used at intermediate and high tidal levels $(-0.5$ to $0.5 \mathrm{~m}$ ) were primarily found along the northern and eastern boundaries of ESNERR. Tagged sharks particularly used the lagoon in the northeast part of ESNERR, the area to the west of the lagoon, and the southeastern region of ESNERR. They were frequently observed making rapid directed movements of hundreds of meters across mudflats to these low intertidal areas, where they would remain until tidal levels dropped, at which point they would make rapid directed movements back to the channel. These movements were regular and highly predictable. 


\section{Main channel sharks ESNERR sharks \\ High tidal levels $(>1.1 \mathrm{~m})$}
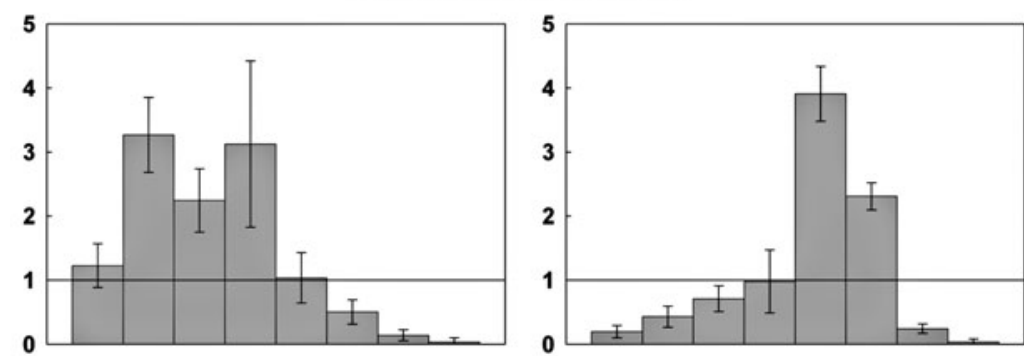

Intermediate tidal levels $(0.5-1.1 \mathrm{~m})$
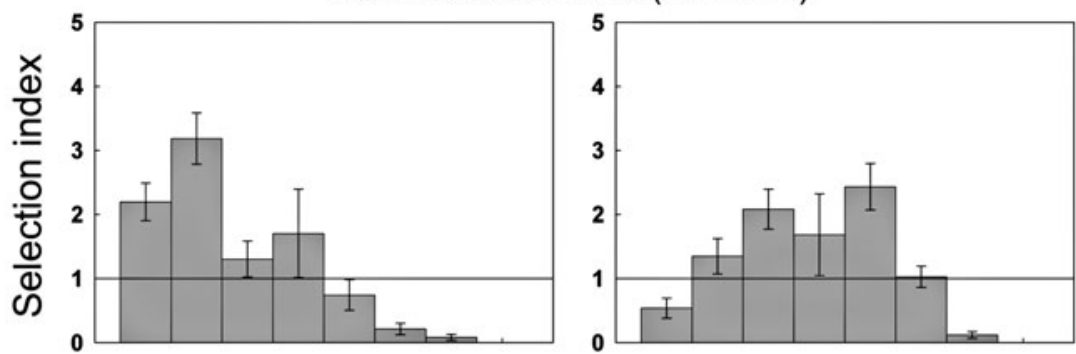

Low tidal levels $(<0.5 \mathrm{~m})$
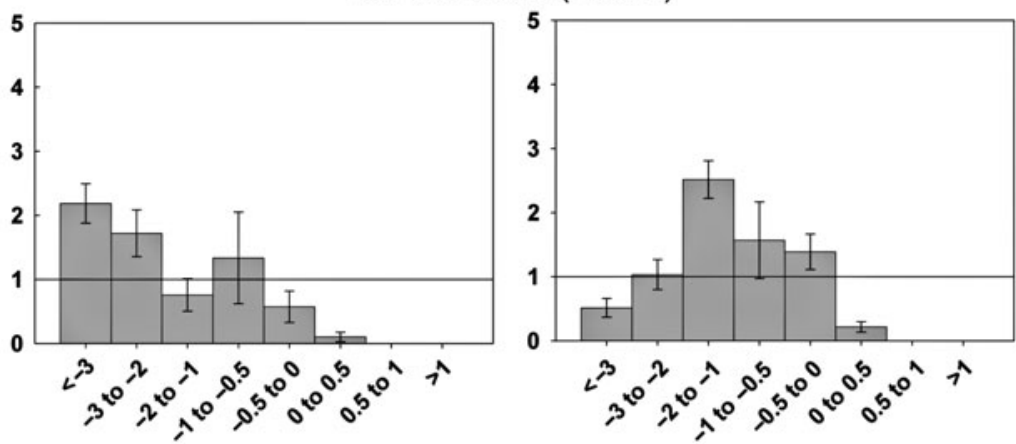

Depth of bottom $(m)$

Fig. 8. Selection indices $( \pm 95 \% \mathrm{CI})$ for habitat categories in main channel $(\mathrm{n}=3)$ and ESNERR $(n=5)$ sharks at different tidal levels. Selection index values $>1$ indicate selection, while values $<1$ indicate avoidance. A value of 1 indicates that the shark is using a habitat type in proportion to its availability

\section{DISCUSSION}

\section{Residency and seasonal abundance}

Female leopard sharks showed a high degree of fidelity to Elkhorn Slough. Once female leopard sharks entered Elkhorn Slough, they did not make forays into coastal waters until they left for the season. Only 1 of the 13 acoustically monitored sharks (100) left the slough and returned during the same season. At least 1 of the leopard sharks tagged in this study exhibited interannual site fidelity to the slough. Although this is not definitive evidence, it suggests that leopard sharks may exhibit some degree of philopatry as has been reported in other elasmobranchs (Feldheim et al. 2002, Hopkins \& Cech 2003, Vaudo \& Lowe 2006). This philopatric behavior may be related to foraging as Elkhorn Slough is a highly productive environment (Barry et al. 1996, Caffrey et al. 2007), but it may also be natal philopatry. Although the extent to which elasmobranchs exhibit natal homing is unclear, there is increasing evidence that elasmobranchs, possibly including leopard sharks (Lewallen et al. 2007), exhibit some level of natal philopatry (Hueter et al. 2005). This has conservation implications as species that are philopatric, especially ones that display natal philopatry, are likely to be especially vulnerable to alteration of important habitats (Hueter et al. 2005).

Detections of tagged sharks at other receiver arrays in the ocean outside of Elkhorn Slough provided additional information on long-term spatial dynamics of leopard sharks in Monterey Bay. All of the tagged sharks were detected intermittently through mid 2007 at receiver arrays in Moss Landing, Monterey, and Carmel Bay, suggesting that these sharks were largely residential within the Monterey Bay area during 2003 to 2007 . This demonstrates that the long-term survival of sharks that have been implanted with tags is high, and that internal implantation is effective for long-term studies.

Our results support the hypothesis that leopard sharks are seasonally abundant in bays and estuaries and that some proportion of the population leaves these areas in winter (Smith \& Abramson 1990, Yoklavich et al. 1991, Hopkins \& Cech 2003). The seasonal decrease in abundance of leopard sharks in Elkhorn Slough is likely related to water temperature and salinity. Hopkins \& Cech (2003) reported that temperature and salinity were the 2 most important factors determining the seasonal abundance of leopard sharks, bat rays Myliobatis californica, and brown smoothhound sharks Mustelus henlei in Tomales Bay. They reported that when temperatures dropped below 10 to $12^{\circ} \mathrm{C}$ in late autumn and winter, leopard sharks left the bay, and returned in early spring when temperatures increased to $>10^{\circ} \mathrm{C}$. The pattern reported by Hopkins \& Cech (2003) is similar to what we observed in Elkhorn Slough. In 2003 and 2004, temperatures in Elkhorn Slough decreased to lev- 
els at or below $12^{\circ} \mathrm{C}$ in late November, and temperatures increased above $12^{\circ} \mathrm{C}$ starting in mid February (ESNERR unpubl. data). Based on catch and tracking data, these time periods correspond to the departure and likely arrival or return of leopard sharks to the slough. Similarly, the lowest salinity levels measured in Elkhorn Slough occurred during the winter rains, when daily average salinity dropped as low as 15 .

Although many sharks left Elkhorn Slough in winter, as many as 5 (3 juveniles, 2 adults) may have remained through the winter. This suggests that a subset of the leopard sharks, such as juveniles, may be more residential. Why some sharks leave the slough in winter while others remain is unknown. Other species that have been shown to exhibit variability in patterns of residency within bays include bonnethead sharks (Heupel et al. 2006), bull sharks Carcharhinus leucas (Heupel \& Simpfendorfer 2008), and cownose rays Rhinoptera bonasus (Collins et al. 2007).

\section{Leopard shark distribution within Elkhorn Slough}

Female leopard shark distribution within Elkhorn Slough changed seasonally. Leopard sharks extensively used ESNERR, especially during the pupping season (spring and early summer), suggesting that female sharks, which have an annual reproductive cycle (Kusher et al. 1992), may have used ESNERR as a nursery area. Shark use of ESNERR decreased in late summer and autumn, likely due to changing environmental conditions. In mid to late summer and early autumn, water temperatures were highest (up to $24^{\circ} \mathrm{C}$ ) and dissolved oxygen levels were lowest (periodically as low as $0 \mathrm{mg} \mathrm{l}^{-1}$ ) in ESNERR (ESNERR unpubl. data). These conditions are physiologically challenging and potentially stressful for sharks. In a study on the effects of hypoxia on 3 species of sharks, Carlson \& Parsons (2001) considered dissolved oxygen levels $<5 \mathrm{mg} \mathrm{l}^{-1}$ as hypoxic since below this point, sharks altered their swimming and respiratory behavior in response to decreased levels of dissolved oxygen. In late summer and early autumn in ESNERR, mean levels of dissolved oxygen were often $<5 \mathrm{mg} \mathrm{l}^{-1}$. During this period, it was common for the dissolved oxygen to decrease below $3 \mathrm{mg} \mathrm{l}^{-1}$ and there were several events when ESNERR became completely anoxic. All adult sharks that were being monitored ceased using ESNERR in August and rarely used the area for the remainder of the year.

Catch data support the observations that shark abundance decreased in ESNERR and increased in the main channel in autumn, corresponding to the time of minimum dissolved oxygen and maximum water temperatures in ESNERR. The period of decreased oxygen and high temperature corresponds with the lowest catch rates of leopard sharks and other elasmobranchs (A. B. Carlisle unpubl. data) experienced in ESNERR, and with the highest catch rates experienced in the main channel. It is likely that use of ESNERR by leopard sharks increased after the period of high temperature and low dissolved oxygen. Shark 100 returned to the slough in late September 2004 and remained almost entirely in ESNERR, possibly because conditions had improved by that time. In 2003, sharks were tagged in ESNERR after the period of high temperature and low oxygen, and these sharks used ESNERR extensively.

Elasmobranchs that use shallow bays and estuaries need to have behavioral or physiological adaptations to low oxygen conditions as hypoxic or anoxic conditions often occur in these environments, either on a seasonal or diel basis. Miklos et al. (2003) reported that the temperature sensitivity of the metabolic rate of leopard sharks is typical of many fishes and elasmobranchs $\left(Q_{10}=2.51\right)$, and theorized that because they have a normal $Q_{10}$, they are able to forage in warm shallow waters at high tide and still meet their oxygen demand under normoxic conditions. However, the high temperatures that occur in ESNERR during late summer and early autumn would increase oxygen demand greatly, which, when combined with hypoxic or anoxic conditions, would make it very difficult or impossible for leopard sharks to obtain enough oxygen to meet their energetic demands. These results suggest that although it is possible for leopard sharks to tolerate short-term exposure to hypoxic conditions through behavioral changes such as increasing gape width or altering swimming speed (Carlson \& Parsons 2001), they react to extended periods of low oxygen and high temperature in a region by avoiding such conditions and moving to regions with increased oxygen and/or decreased temperature.

The increased use of the lower and mid region of the main channel late in the year is likely caused by declining temperature and salinity. The highest levels of freshwater input occur in the upper region. Areas in the upper slough that are shallower and farther from the ocean experience more extreme conditions than areas in the lower and mid regions, which are more stable due to their proximity to the ocean (Caffrey \& Broenkow 2002). As a result, when temperature and salinity levels decrease during late autumn and winter, they decrease more rapidly in the upper slough than they do in the more stable lower areas of the slough. We surmise that sharks move to the mid and lower slough in late autumn, and then into the ocean, after encountering rapidly dropping temperature and salinity levels in the upper slough. Metabolic and physiological processes of ectothermic sharks are strongly influenced by temperature (Matern et al. 2000, Lowe 
2001, Carlson et al. 2004). Moreover, changes in ambient salinity also impact elasmobranchs through the metabolic cost and physiological impacts associated with changing salinity and osmoregulation (Evans et al. 2004). Temperature and salinity are therefore likely to be important factors that influence the abundance, residency and distribution of leopard sharks (and other elasmobranchs) in bays and estuaries (Snelson \& Williams 1981, Hopkins \& Cech 2003, Simpfendorfer et al. 2005, Abel et al. 2007).

Although the relationship between the distribution of sharks in Elkhorn Slough and environmental conditions is correlative, it provides a potential causal relationship. However, an alternative explanation is that leopard shark prey are also influenced by changing environmental conditions. Benthic invertebrates and estuarine and coastal fishes are known to be sensitive to low levels of oxygen (Rosenberg et al. 1991, Diaz \& Rosenberg 1995, Breitburg 2002, Vaquer-Sunyer \& Duarte 2008). It is thus possible that hypoxic and anoxic conditions caused changes in the distribution and abundance of leopard shark prey in Elkhorn Slough. A shift in prey distribution or abundance, triggered by changing environmental conditions, could result in a change in the distribution of leopard sharks, especially if leopard sharks are similarly sensitive to adverse environmental conditions.

\section{Habitat use}

Tidal state greatly influenced the habitat use of leopard sharks. Sharks did not passively move with the advancing tide, but moved with the tide to lower intertidal habitats as soon as they were available, whereupon the sharks stopped and remained until the ebbing tides forced them back to the channels. Ackerman et al. (2000) reported that leopard sharks move with the tide to forage in intertidal mudflats and then move back out with the ebb tide. Young sandbar sharks Carcharhinus plumbeus (Medved \& Marshall 1983, Wetherbee et al. 2001), dusky sharks Carcharhinus obscurus (Huish \& Benedict 1977), Atlantic stingrays Dasyatis sabina (Teaf 1980), cownose rays Rhinoptera bonasus (Smith \& Merriner 1985), spotted eagle rays Aetobatus narinari (Silliman \& Gruber 1999), and southern stingrays Dasyatis americana (Gilliam \& Sullivan 1993) have all been reported to exhibit tidal movements that are possibly related to foraging. Although very small leopard sharks may occasionally be consumed by larger conspecifics (Ackerman 1971), there are no major predators of leopard sharks in Elkhorn Slough (Yoklavich et al. 1991, Carlisle et al. 2007). This suggests that for leopard sharks in Elkhorn Slough, patterns of habitat use are more influenced by prey availability than by predator avoidance, which has been shown to be an important factor influencing habitat use in other elasmobranch species (Morrissey \& Gruber 1993, Heupel \& Hueter 2002, Duncan \& Holland 2006). Also, it is possible that shark use of shallow intertidal mudflats may be thermoregulatory in nature, and reflects behavior that increases physiological, digestive, and metabolic rates (Carlson et al. 2004, Hight \& Lowe 2007). However, if thermoregulation were the primary factor, we would predict that sharks would use the shallowest and warmest habitats available (i.e. high intertidal mudflats), and that use of these habitats would primarily occur during the day. Instead, sharks avoided these habitats, and habitat use was not influenced by time of day. This does not mean that sharks do not derive a thermoregulatory benefit from utilizing the shallow waters of the slough (and ESNERR in particular), but that thermoregulation does not appear to be the primary causal factor in habitat use.

In addition to its possible role as a nursery area, it is likely that ESNERR is used extensively by female leopard sharks due to the abundance of low intertidal mudflats and prey items that occur in these habitats. ESNERR contains $\sim 43 \%$ of the low intertidal mudflats $(-0.5$ to $0.5 \mathrm{~m})$ in the slough, and unlike in the main channel where these habitats are generally narrow bands along the main channel, the mudflats in ESNERR make up large areas of continuous habitat. The large number of apparent feeding pits (A. B. Carlisle pers. obs.) in the lower intertidal zone in ESNERR indicates that leopard sharks (and/or other elasmobranchs) were foraging in intertidal habitats, are likely an important source of bioturbation in the slough, and may influence invertebrate infaunal communities (VanBlaricom 1982).

These intertidal habitats potentially provide leopard sharks with an abundance of prey items, especially fat innkeeper worms Urechis caupo. According to Kao (2000), the single most important prey item of leopard sharks in Elkhorn Slough is the fat innkeeper worm, on which they feed intensively when in ESNERR. Although there have been no rigorous surveys, fat innkeeper worms appear to be abundant in ESNERR where they are present subtidally and intertidally (Kao 2000, A. B. Carlisle pers. obs.), and are likely to be abundant in the low intertidal zone (Ricketts et al. 1985). Although fat innkeeper worms are of lesser caloric density per unit volume than fishes, Kao (2000) suggested that they were a more abundant and spatially reliable food source compared to fishes. In addition to harboring fat innkeeper worms, ESNERR appears to harbor a greater abundance of important leopard shark prey items such as teleosts and infaunal and epibenthic invertebrates relative to the other 
regions of the slough (lower, mid, and upper main channel) (Nybakken et al. 1977, Barry 1983, Yoklavich et al. 1991, 2002, Kao 2000, Wasson et al. 2002).

The small activity spaces and strong fidelity of leopard sharks to ESNERR for extended periods of time support the theory that the area contains high quality habitat and abundant prey resources. The activity spaces of sharks tracked in ESNERR were half the size of activity spaces of sharks tracked in the main channel, suggesting that an abundance of prey allowed sharks to forage over smaller areas. In addition, almost all of the sharks used ESNERR extensively throughout the year and often remained for weeks or months at a time without leaving. This fidelity is striking because in order to remain in ESNERR, sharks had to actively swim against the strongest currents that occur in the slough on a daily basis (up to $1.7 \mathrm{~m} \mathrm{~s}^{-1}$ in the channel that connects ESNERR to the main channel; Caffrey \& Broenkow 2002). This suggests that not only was there enough prey to support relatively high densities of sharks for extended periods of time, but also that prey was abundant enough or some other characteristic of ESNERR was advantageous enough that sharks actively moved to remain in ESNERR despite strong tidal forces that would otherwise carry them out of ESNERR during ebb tides.

Leopard sharks in the main channel exhibited a different pattern of habitat use than sharks in ESNERR, likely due to differences in the availability and distribution of important habitat (i.e. low intertidal mudflats) and prey. Sharks in the main channel primarily used subtidal habitats, indicating that intertidal mudflats in the main channel are less important than those in ESNERR. Most of the intertidal mudflats in the main channel are in the mid and upper slough, and these are primarily higher intertidal mudflats of the type that sharks avoided. Moreover, although $\sim 57 \%$ of the low intertidal mudflats in the slough are in the main channel, they form a narrow band along the main channel and do not form large continuous areas of habitat as in ESNERR. Most importantly, the primary intertidal prey item of leopard sharks, the fat innkeeper worm, is restricted to the lower parts of the main channel where, possibly due to the relative lack of low intertidal mudflats in the lower slough, it is most abundant subtidally (Jolly 1997). There is thus no reason for leopard sharks to extensively utilize intertidal mudflats in the main channel; most of the mudflats in the main channel are of a type that sharks avoided and none of its major prey items, especially fat innkeeper worms, are particularly abundant in intertidal habitats. This does not mean that sharks in the main channel do not forage intertidally, but that use of these habitats is much lower than in ESNERR.

Although we did not survey the invertebrate or fish fauna of Elkhorn Slough to evaluate our hypothesis that sharks differentially use habitats based on the abundance of prey, we reviewed existing information on the distribution of leopard shark prey items in Elkhorn Slough (e.g. Nybakken et al. 1977, Yoklavich et al. 1991, 2002, Wasson et al. 2002). We suggest that habitat use by leopard sharks reflects an interaction between abundance and distribution of important prey items and important habitats. Sharks use intertidal mudflats where there is an abundance of prey, especially fat innkeeper worms, but not mudflats that have a relatively depauperate prey field relative to neighboring subtidal habitats. Mudflats that experience more variable and extreme environmental conditions, such as high intertidal mudflats or mudflats in the upper region of the slough, generally harbor fewer prey items (Beukema 1976, Dittmann 2000, 2002, Wasson et al. 2002) and are less frequently utilized by leopard sharks. It also appears that the size of low intertidal mudflats is important, with large areas of continuous mudflats being better shark habitat than narrow bands bordering subtidal areas. Thus, we suggest that optimal habitat for leopard sharks in Elkhorn Slough contains large continuous areas of low intertidal mudflats that support a relatively diverse community that includes fat innkeeper worms (and other important prey items). Because intertidal mudflats are important habitat not only for elasmobranchs, but also for invertebrates, teleosts, marine mammals and birds, the protection of these habitats would likely have wide-ranging benefits in terms of maintaining the biodiversity and health of bays and estuaries.

Leopard sharks and other elasmobranchs use shallow bays and estuaries extensively throughout their life history, especially as foraging and nursery areas. In addition to being susceptible to overexploitation because of their life history characteristics (Cailliet 1992), leopard sharks are also vulnerable to the loss of critical habitats in bays and estuaries, especially if they exhibit philopatric behavior. Rates of erosion in Elkhorn Slough continue to be great, and continued habitat alteration will likely negatively affect populations of leopard sharks, thus altering the role that these sharks play in the estuarine food web. Because of this, it is important to identify and protect critical habitats in bays and estuaries. This research has shown that leopard shark movements in Elkhorn slough are nonrandom with respect to tidal level and habitat and are influenced by bottom depth, habitat characteristics, and prey distribution. This work provides the basis for a framework within which to make predictions about how leopard shark habitat use may change in the future given different scenarios, such as estuarine filling, dredging, erosion, or sea level rise due to climate change. 
Acknowledgements. We thank the many people that volunteered their time to assist with this project, particularly $\mathrm{M}$. Plank, M. Carlisle, P. Carlisle, S. Carlisle, B. C. P. Homer, C. Rinewalt, M. Segal, V. Hunt, A. Thurber, R. Sanders, C. Davis, T. Schaadt, E. Tanadjaja, B. Doolittle, L. Wertz, E. Woolery, R. Leaf, L. McConnico, A. Melwani, A. Willis, H. Nevins, C. Schnitzler, C. Perez, A. Greenley, D. Tanner, J. Grebel, B. Flammang, W. Watson, and J. Felton. We also thank G. Cailliet, J. Harvey, D. Ebert, J. Bizzarro, W. Smith, M. Levey, L. Breaker, and M. Graham for their valuable advice; the Elkhorn Slough National Estuarine Research Reserve staff for their assistance; and S. V. Sommeran and the Pelagic Shark Research Foundation for returning several acoustic tags. This work was conducted under San Jose State University IACUC Protocol \#813. Funding was provided by the PADI Foundation, the Dr. Earl H. Myers and Ethel M. Myers Oceanographic and Marine Biology Trust, the Archimedes Scholarship, PADI Project AWARE, a NOAA/NMFS grant to the National Shark Research Consortium (NSRC) Pacific Shark Research Center (PSRC), the Packard Foundation, and the University of California Sea Grant Extension Program.

\section{LITERATURE CITED}

Abel DC, Young RF, Garwood JA, Travaline MJ, Yednock BK (2007) Survey of the shark fauna in two South Caroline estuaries and the impact of salinity structure. In: McCandless CT, Pratt HL Jr, Kohler NE (eds) Shark nursery grounds of the Gulf of Mexico and East Coast waters of the United States. Am Fish Soc Symp 50:109-124

Ackerman LT (1971) Contributions to the biology of the leopard shark, Triakis semifasciata (Girard), in Elkhorn Slough, Monterey Bay, California. MA thesis, Sacramento State College, CA

Ackerman JT, Kondratieff MC, Matern SA, Cech JJ (2000) Tidal influence of statial dynamics of leopard sharks, Triakis semifasciata, in Tomales Bay, California. Environ Biol Fishes 58:33-43

Barry JP (1983) Utilization of shallow marsh habitats by fishes in Elkhorn Slough, California. MSc thesis, San Jose State University, CA

Barry JP, Yoklavich MM, Cailliet GM, Ambrose DA, Antrim BS (1996) Trophic ecology of the dominant fishes in Elkhorn Slough, California, 1974-1980. Estuaries 19: 115-138

Bascompte J, Melian CJ, Sala E (2005) Interaction strength combinations and the overfishing of a marine food web. Proc Natl Acad Sci USA 102:5443-5447

Beukema JJ (1976) Biomass and species richness of the macrobenthic animals living on the tidal flats of the Dutch Wadden Sea. Neth J Sea Res 10:236-261

Breitburg D (2002) Effects of hypoxia, and the balance between hypoxia and enrichment, on coastal fishes and fisheries. Estuaries 25:767-781

Broenkow W (1977) Water chemistry of Elkhorn Slough and Moss Landing Harbor. In: Nybakken J, Cailliet GM, Broenkow W (eds) Ecologic and hydrographic studies of Elkhorn Slough, Moss Landing Harbor, and nearshore coastal waters. Moss Landing Marine Laboratories Technical Report, Moss Landing, CA, p 387-465

Broenkow WW, Breaker LC (2005) A 30-year history of tide and current measurements in Elkhorn Slough, California. Moss Landing Marine Laboratories, Moss Landing, CA

Caffrey J, Broenkow W (2002) Hydrography. In: Caffrey J, Brown M, Tyler WB, Silberstein M (eds) Changes in a California estuary: a profile of Elkhorn Slough. Elkhorn
Slough Foundation, Moss Landing, CA, p 29-42

Caffrey JM, Chapin TP, Jannasch HW, Haskins JC (2007) High nutrient pulses, tidal mixing and biological response in a small California estuary: variability in nutrient concentrations from decadal to hourly time scales. Estuar Coast Shelf Sci 71:368-380

Cailliet GM (1992) Demography of the Central California population of the leopard shark Triakis semifasciata. Aust J Mar Freshw Res 43:183-193

Carlisle A, King A, Cailliet GM, Brennan JS (2007) Long-term trends in catch composition from elasmobranch derbies in Elkhorn Slough, California. Mar Fish Rev 69:25-45

Carlson JK, Parsons GR (2001) The effects of hypoxia on three sympatric shark species: physiological and behavioral responses. Environ Biol Fishes 61:427-433

Carlson JK, Goldman KJ, Lowe CG (2004) Metabolism, energetic demand, and endothermy. In: Carrier JC, Musick JA, Heithaus MR (eds) Biology of sharks and their relatives. CRC Press, Boca Raton, FL, p 203-224

> Castro JI (1993) The shark nursery of Bulls Bay, South Carolina, with a review of the shark nurseries of the southeastern coast of the United States. Environ Biol Fishes 38: $37-48$

Collins AB, Heupel MR, Motta PJ (2007) Residence and movement patterns of cownose rays Rhinoptera bonasus within a south-west Florida estuary. J Fish Biol 71:1159-1178

Diaz RJ, Rosenberg R (1995) Marine benthic hypoxia: a review of its ecological effects and the behavioral responses of benthic macrofauna. Oceanogr Mar Biol Annu Rev 33:245-303

> Dittmann S (2000) Zonation of benthic communities in a tropical tidal flat of north-east Australia. J Sea Res 43:33-51

> Dittmann S (2002) Benthic fauna in tropical tidal flats of Hinchinbrook Channel, NE Australia: diversity, abundance and their spatial and temporal variation. Wetl Ecol Manag 10:323-333

> Duncan KM, Holland KN (2006) Habitat use, growth rates and dispersal patterns of juvenile scalloped hammerhead sharks Sphyrna lewini in a nursery habitat. Mar Ecol Prog Ser 312:211-221

Ebert DA (2003) Sharks, rays and chimaeras of California. University of California Press, Berkeley, CA

Edgar GJ, Barrett NS, Graddon DJ, Last PR (2000) The conservation significance of estuaries: a classification of Tasmanian estuaries using ecological, physical and demographic attributes as a case study. Biol Conserv 92: 383-397

Evans DH, Piermarini PM, Choe KP (2004) Homeostasis: osmoregulation, $\mathrm{pH}$ regulation and nitrogen secretion. In: Carrier JC, Musick JA, Heithaus MR (eds) Biology of sharks and their relatives. CRC Press, Boca Raton, FL, p 247-268

> Feldheim KA, Gruber SH, Ashley MV (2002) The breeding biology of lemon sharks at a tropical nursery lagoon. Proc R Soc Lond B Biol Sci 269:1655-1661

Gilliam D, Sullivan KM (1993) Diet and feeding habits of the southern stingray Dasyatis americana in the Central Bahamas. Bull Mar Sci 52:1007-1013

Heupel MR, Hueter RE (2002) Importance of prey density in relation to the movement patterns of juvenile blacktip sharks (Carcharhinus limbatus) within a coastal nursery area. Mar Freshw Res 53:543-550

Heupel MR, Simpfendorfer CA (2008) Movement and distribution of young bull sharks Carcharhinus leucas in a variable estuarine environment. Aquat Biol 1:277-289

Heupel MR, Simpfendorfer CA, Collins AB, Tyminski JP (2006) Residency and movement patterns of bonnethead sharks, Sphyrna tiburo, in a large Florida estuary. Environ 
Biol Fishes 76:47-67

Hight BV, Lowe CG (2007) Elevated body temperatures of adult female leopard sharks, Triakis semifasciata, while aggregating in shallow nearshore embayments: evidence for behavioral thermoregulation? J Exp Mar Biol Ecol 352: $114-128$

Holland KN, Wetherbee BM, Lowe CG, Meyer CG (1999) Movements of tiger sharks (Galeocerdo cuvier) in coastal Hawaiian waters. Mar Biol 134:665-673

Hooge PN, Eichenlaub B (2000) Animal movement extension to Arcview. Ver. 2.0. Alaska Science Center - Biological Science Office, U.S. Geological Survey, Anchorage, AK

Hopkins TE, Cech JJ Jr (2003) The influence of environmental variables on the distribution and abundance of three elasmobranchs in Tomales Bay, California. Environ Biol Fishes 66:279-291

Hueter RE, Heupel MR, Heist EJ, Keeney DB (2005) Evidence of philopatry in sharks and implications for the management of shark fisheries. J Northwest Atl Fish Sci 35: 239-247

Huish MT, Benedict C (1977) Sonic tracking of dusky sharks in Cape Fear River, North Carolina. J Elisha Mitchell Sci Soc 93:21-26

Jolly JM (1997) Foraging ecology of the sea otter, Enhydra lutris, in a soft-sediment community. MSc thesis, University of California at Santa Cruz, CA

Kao JS (2000) Diet, daily ration and gastric evacuation of the leopard shark (Triakis semifasciata). MSc thesis, California State University, Hayward, CA

Krebs CJ (1999) Ecological methodology. Addison-Wesley Educational Publishers, Menlo Park, CA

Kusher DI, Smith SE, Cailliet GM (1992) Validated age and growth of the leopard shark (Triakis semifasciata) with comments on reproduction. Environ Biol Fishes 35:187-203

Larson EJ (2001) Coastal wetlands - emergent marshes. In: Leet WS, Dewees CM, Klingbeil R, Larson EJ (eds) California's living marine resources: a status report. Publication SG01-11, California Department of Fish and Game, Monterey, CA, p 483-486

Lewallen EA, Anderson TW, Bohonak AJ (2007) Genetic structure of leopard shark (Triakis semifasciata) populations in California waters. Mar Biol 152:599-609

Lindquist DC (1998) The effects of erosion on the trophic ecology of fishes in Elkhorn Slough, CA. MSc thesis, California State University, Hayward, CA

Lowe CG (2001) Metabolic rates of juvenile scalloped hammerhead sharks (Sphyrna lewini). Mar Biol 139:447-453

Malzone CM (1999) Tidal scour and its relation to erosion and sediment transport in Elkhorn Slough. MSc thesis, San Jose State University, CA

Manly BFJ, McDonald LL, Thomas DL, McDonald TL, Erickson WP (2002) Resource selection by animals: statistical design and analysis for field studies. Kluwer Academic Publishers, Dordrecht

> Matern SA, Cech JJ, Hopkins TE (2000) Diel movements of bat rays, Myliobatis californica, in Tomales Bay, California: evidence for behavioral thermoregulation? Environ Biol Fishes 58:173-182

Medved RJ, Marshall JA (1983) Short-term movements of young sandbar sharks, Carcharhinus plumbeus (Pisces, Carcharhinidae). Bull Mar Sci 33:87-93

> Miklos P, Katzman SM, Cech JJ (2003) Effect of temperature on oxygen consumption of the leopard shark, Triakis semifasciata. Environ Biol Fishes 66:15-18

Morrissey JF, Gruber SH (1993) Habitat selection by juvenile lemon sharks, Negaprion brevirostris. Environ Biol Fishes 38:311-319
Musick JA, Burgess G, Cailliet G, Camhi M, Fordham S (2000) Management of sharks and their relatives (Elasmobranchii). Fisheries 25:9-13

Nybakken JW, Cailliet GM, Broenkow WW (1977) Ecological and hydrographic studies of Elkhorn Slough, Moss Landing harbor, and nearshore coastal waters, July 1974 to June 1976. Moss Landing Marine Laboratories Technical Publication, Moss Landing, CA

Ricketts EF, Calvin J, Hedgepeth JW (1985) Between Pacific tides, 5th edn (revised by Phillips DW). Stanford University Press, Stanford, CA

- Rosenberg R, Hellman B, Johansson B (1991) Hypoxic tolerance of marine benthic fauna. Mar Ecol Prog Ser 79: $127-131$

Silliman WR, Gruber SH (1999) Behavioral ecology of the spotted eagle ray, Aetobatus narinari (Euphrasen, 1790), in Bimini, Bahamas; an interim report. Bahamas J Sci 7:13-20

Simpfendorfer CA, Milward NE (1993) Utilization of a tropical bay as a nursery area by sharks of the families Carcharhinidae and Sphyrnidae. Environ Biol Fishes 37:337-345

Simpfendorfer CA, Freitas GG, Wiley TR, Heupel MR (2005) Distribution and habitat partitioning of immature bull sharks (Carcharhinus leucas) in a southwest Florida estuary. Estuaries 28:78-85

Smith SE, Abramson NJ (1990) Leopard shark Triakis semifasciata distribution, mortality rate, yield, and stock replenishment estimates based on a tagging study in San Francisco Bay. Fish Bull (Wash DC) 88:371-381

> Smith JW, Merriner JV (1985) Food habits and feeding behavior of the cownose ray, Rhinoptera bonasus, in lower Chesapeake Bay. Estuaries 8:305-310

Snelson FF, Williams SE (1981) Notes on the occurrence, distribution, and biology of elasmobranch fishes in the Indian River Lagoon System, Florida. Estuaries 4:110-120

Springer S (1967) Social organization of shark populations. In: Gilbert PW, Mathewson RF, Rall DP (eds) Sharks, skates, and rays. Johns Hopkins Press, Baltimore, MD, p 149-174

Stevens JD, Bonfil R, Dulvy NK, Walker PA (2000) The effects of fishing on sharks, rays, and chimaeras (chondrichthyans), and the implications for marine ecosystems. ICES J Mar Sci 57:476-494

Talent LG (1976) Food habits of leopard shark, Triakis semifasciata, in Elkhorn Slough, Monterey Bay, California. Calif Fish Game 62:286-298

Talent LG (1985) The occurrence, seasonal distribution, and reproductive condition of elasmobranch fishes in Elkhorn Slough, California. Calif Fish Game 71:210-219

Teaf CM (1980) A study of the tidally oriented movements of the Atlantic stingray, Dasyatis sabina (LeSeur), in Appalachee Bay, Florida. MSc thesis, Florida State University, Tallahassee, FL

Van Dyke E, Wasson K (2005) Historical ecology of a central California estuary: 150 years of habitat change. Estuaries 28:173-189

VanBlaricom GR (1982) Experimental analyses of structural regulation in a marine sand community exposed to oceanic swell. Ecol Monogr 52:283-305

Vaquer-Sunyer R, Duarte CM (2008) Thresholds of hypoxia for marine biodiversity. Proc Natl Acad Sci USA 105: 15452-15457

> Vaudo JJ, Lowe CG (2006) Movement patterns of the round stingray Urobatis halleri (Cooper) near a thermal outfall. J Fish Biol 68:1756-1766

Wasson K, Kviteck R, Nybakken J, Braby C, Silberstein M (2002) Invertebrates. In: Caffrey J, Brown M, Tyler WB, Silberstein M (eds) Changes in a California estuary: a profile of Elkhorn Slough. Elkhorn Slough Foundation, Moss 
Landing, CA, p 163-186

Wetherbee BM, Rechisky EL, Pratt HL, McCandless CT (2001) Use of telemetry in fisheries management: juvenile sandbar sharks in Delaware Bay. In: Sibert J, Nielsen JL (eds) Electronic tagging and tracking in marine fisheries. Kluwer Academic Publishers, Dordrecht, p 249-262

Whitfield AK, Elliot M (2002) Fishes as indicators of environmental and ecological changes in estuaries: a review of progress and some suggestions for the future. J Fish Biol 61:229-250

Worton BJ (1989) Kernel methods for estimating the utiliza-

Editorial responsibility: Matthias Seaman,

Oldendorf/Luhe, Germany tion distribution in home-range studies. Ecology 70 : 164-168

Yoklavich MM, Cailliet GM, Barry JP, Ambrose DA, Antrim BS (1991) Temporal and spatial patterns in abundance and diversity of fish assemblages in Elkhorn Slough, California. Estuaries 14:465-480

Yoklavich MM, Cailliet GM, Oxman D, Barry JP, Lindquist DC (2002) Fishes. In: Caffrey J, Brown M, Tyler WB, Silberstein $M$ (eds) Changes in a California estuary: a profile of Elkhorn Slough. Elkhorn Slough Foundation, Moss Landing, CA, p 163-186

Submitted: October 22, 2008; Accepted: December 22, 2008 Proofs received from author(s): March 20, 2009 